\title{
Muutos ja oppiminen työterveyshuollossa
}

\author{
Camilla Kovero
}

\author{
Jotta olisi mahdollista vaikuttaa omaan toimintaan \\ ja valita vaihtoehtoisia toimintamalleja sekä kehittää \\ oppivaa ympäristöä, tulee tärkeäksi lisätä tietoisuutta \\ muutoksesta ilmiönä, eri vaiheista muutosprosessin \\ aikana, niin ympäristön eri tasojen välillä kuin suhteessa \\ työterveyshuoltoon. Aikaisemman tilan sulattaminen \\ on välttämätön muutoksen käynnistämiseksi.
}

$\mathrm{T}$ utkimustapa terveysneuvonnassa ja työterveyshuollossa oli aikaisemmin positivistisesti suuntautunut. Tutkimusongelmat liittyivät kemiallisiin, fysikaalisiin ja lääketieteellisiin kysymyksiin. Ihmiskäsitys oli biologinen, esimerkiksi ihmisen työkykyä tarkasteltiin sairaus-, riski- tai ongelmalähtöisesti. Positivistisella lähestymistavalla on pitkät perinteet myös kasvatustieteellisessä ja yhteiskuntatieteellisessä tutkimuksessa.

Eksaktit luonnontieteet toimivat positivistisen lähestymistavan ihanteena. Ongelmiin etsittiin syy-seuraus -yhteyksiä ja tutkimuksen tavoitteena oli saada selville säännönmukaisia lainalaisuuksia, joita voitiin soveltaa käytännössä. Tunnusomaista oli edelleen ajatus yhdestä yleispätevästä metodista, jota käytetään siitä riippumatta, mitä aluetta tutkitaan. Luonnontieteellisiä metodeja käyttäen oli mahdollista tehdä objektiivisia ratkaisuja ja aikaansaada tieteellisiä selityksiä niin kasvatus- ja hoitotieteellisiin kuin myös yhteiskunnallisiin ongelmiin.

Lähestymistapaa on jo kauan kritisoitu, esimer- kiksi Thomas Kuhnin esittää vaikutusvaltaista ktitiikkiä vuonna 1962 julkaisemassaan teoksessa "The Structure of the Scientific revolutions". Kuhn hylkää käsityksen tiedon objektiivisuudesta ja neutraalisuudesta ja väittää, että tieto on pikemminkin subjektiivista, kontekstisidonnaista, normatiivista ja aina poliittista.

$\mathrm{K}$ un tutkitaan ihmillistä käyttäytymistä, ajatuksia ja kokemuksia, tarvitaan metodeja, jotka auttavat ymmärtämään ihmisen omia käsityksiä todellisuudesta. Tulkitsevalla lähestymistavalla on monta teoreettista traditiota. Fenomenologiaan sisältyy ajatus, että ihmisen kehitykseen eivät vaikuta ainoastaan ympäristön objektiiviset olosuhteet, vaan pikemmin ne subjektiiviset merkitykset, joita ihminen antaa ilmiöille. Yhteiskunnalliset ilmiöt eivät ole riippumattomia järjestelmiä, joita ulkoiset tekijät ylläpitävät. Tulkitsevan sosiaalisen tutkimuksen tehtävänä on valaista niitä merkityksiä ja käsityksiä joita ihmiset antavat teoilleen, ja siten lisätä ymmärrystä sosiaalisesta toiminnasta. Tavoitteena ei ole tuottaa kausaalisia selityksiä, vaan syventää tietoa sii- 
tä, miten sosiaalinen elämä tulkitaan (Schutz 1967).

Fenomenologinen lähestymistapa oli tutkimuksessani välttämätön, koska tarkoituksena oli kuvata ja ymmärtää, miten terveydenhoitajat, lääkärit ja fysioterapeutit kokevat todellisuuden. Tekojen ja suhtautumisen subjektiivisen ymmärryksen lisääminen ei kuitenkaan ole riittävää, kun kiinnostuksen kohteena on myös ihmisen ja hänen sosiaalisen ympäristönsä vuorovaikutus. Vaikka on totta, että tietoisuus määrittelee todellisuuden, on myös totta, että todellisuus voi väärentää tietoisuutta. Tästä syystä tulee sellaiseen kasvatustieteelliseen ja yhteiskuntatieteelliseen tutkimukseen, jossa kiinnostuksen kohteena on sosiaalisen järjestelmän muutos ja kehittyminen, myös sisältyä sekä oman suhtautumisen että vallitsevien sosiaalisten ja organisatoristen normien ja arvojen kriittinen kyseenalaistaminen.

$\mathrm{T}$ utkimuksessani lähestymistapa on kriittinen. Kiinnostuksen kohteena on ymmärtää ja kuvata informanttien kokemuksia ja käsityksiä omasta toiminnastaan ja sen muutoksista sekä analysoida tulevan tiedon tarvetta suhteessa toiminnan muutokseen ja oman ammattiroolin kehitykseen. Tarkoituksena on edelleen valaista ihmisen toiminnan ja sosiaalisen ympäristön suhdetta ja siten lisätä mahdollisuutta valita vaihtoehtoisia toimitapoja ja vaikuttaa toiminnan kehitykseen.

Jürgen Habermasin (1971) mukaan ihmisen suh-

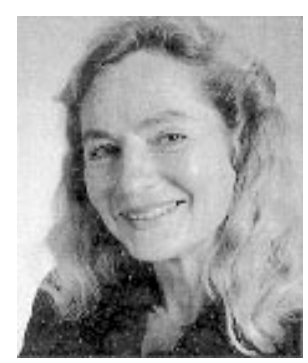

Camilla Kovero

tautuminen ja mahdollisuus toteuttaa pyrkimyksiä voivat olla objektiivisten, sosiaalisten yhteyksien tulos, jotka rajoittavat ja väärentävät ymmärrystä. Kriittinen lähestymistapa kyseenalaistaa epäkriittistä itseymmärrystä ja pyrkii näkemään sen taakse, jotta olisi mahdollista saada tietoa niistä yhteyksistä jotka luovat perustan kommunikaatiolle ja sosiaaliselle toiminnalle. Kaikki tämä, jotta emansipaatio, vapaus ja rationaalinen autonomia olisivat mahdollisia.

Erona muihin terveyspalvelujärjestelmiin työterveyshuollon tavoitteena on paitsi edistää yksilöiden terveyttä, myös parantaa työoloja ja työympäristöä. Lakisääteinen työterveyshuolto on runsaan 25-vuoden kehityksen aikana käynyt läpi merkittäviä muutoksia. Toiminta kattaa nyt suurimman osan työtätekevästä väestöstä. Laadullinen muutos aikaisempaan riski-, ongelma- ja toimenpidesuuntautuneeseen lähestymistapaan näkyy nyt työterveyshuollon korostamisena asteittain etenevänä prosessina, jossa ennaltaehkäisevät, hoitavat ja kuntouttavat toimenpiteet vaihtelevat, riippuen työpaikan ja työntekijöiden tarpeista.

\begin{tabular}{|c|c|c|c|}
\hline & Vapaaehtoinen & Lait ja määräykset & Paikallinen suunnittelu \\
\hline TAVOITE & $\begin{array}{l}\text { sairaussuuntau- } \\
\text { tunut }\end{array}$ & $\begin{array}{l}\text { riski- ja ongelma- } \\
\text { suuntautunut }\end{array}$ & kokonaisvaltainen \\
\hline MENETELMÄT & hoitava, korjaava & & terveyttä edistävä \\
\hline TYÖNLUONNE & passiivinen & aktiivinen & tarvesuuntautunut \\
\hline KOHDERYHMÄ & yksilö & $\begin{array}{l}\text { yksilö - } \\
\text { työympäristö }\end{array}$ & $\begin{array}{l}\text { yksilö, työkokonaisuus } \\
\text { ja työympäristö }\end{array}$ \\
\hline KATTAVUUS & $30 \%$ & $80 \%$ & $90 \%$ \\
\hline AJANJAKSO & $1930-->\quad 1978$ & $1980--->$ & $1990--->$ \\
\hline TYÖTERVEYSHUOLTO & $\begin{array}{l}\text { perusterveyden- } \\
\text { hoito }\end{array}$ & ennaltaehkäisevä & yhteistyö \\
\hline
\end{tabular}

Kuvio 1. Työterveyshuollon kehitysvaiheet (muunneltu Rantasen 1997, Luopajärven 1997 mukaan). 


\section{UU T T A T U T K I M U K S E S T A}

Haasteet, jotka nykyään kohdistuvat työterveyshuoltoon, johtuvat toisaalta muuttuneista ulkoisista olosuhteista, kuten muutoksista niissä laeissa ja virallisissa ohjesäännöissä, jotka luovat perustan toiminnan liikkumavapaudelle, kuten myös muutoksista väestön ikärakenteessa sekä työelämän muuttuneista olosuhteista. Luonteenomaisia piirteitä tämän päivän työelämälle ovat paitsi nopea tekninen kehitys, uudet tuotantoja työmenetelmät, myös työelämän rationalisointipyrkimykset sekä kaikkiin työntekijöihin kohdistuva tehokkuusvaatimus.

Aikaisempi riski- ja ongelmalähtöinen suhtautuminen ihmisen työkykyyn on muuttunut. Nykyään suhtautuminen on kokonaisvaltaisempaa ja koostuu fyysisten, psyykkisten ja sosiaalisten tekijöiden vuorovaikutuksesta (Rantanen 1997). Samanaikaisesti kun työterveyshuoltoon kohdistuu uusia haasteita, ovat yhteiskunnan, yritysten ja työntekijöiden toimintaan kohdistuvat vaatimukset ja odotukset kasvaneet. Työterveyshuollon tärkeimpiä tehtäviä tulevina vuosina on ylläpitää suurten ikäluokkien työkykyä. Työelämäntutkimukset osoittavat kuitenkin, miten uupumisen ja loppuunpalamisen riskit ovat lisääntyneet eri ammattiryhmien jäsenten keskuudessa (esimerkiksi Kalimo \& Toppinen 1997, Lehto \& Sutela 1998).

$\mathrm{T}$ yöterveyshuolto on palvelujärjestelmä, joka toimii lähellä kohderyhmiään. Se antaa suosituksia työnantajille ja esimiehille, mutta sillä ei ole päätäntävaltaa. Työterveyshuoltohenkilöstö työskentelee hierarkkisissa organisaatioissa, joissa autonomisten päätösten mahdollisuudet vaihtelevat. Kun kyseessä on työterveyshuollon arkiset käytännöt, kuten työnjako omassa yksikössä tai työmenetelmien ja työvälineiden valinta, autonomisten päätösten mahdollisuudet ovat hyvät. Sitä vastoin kontrollimahdollisuudet ovat pienet, kun kyseessä ovat organisatoriset päätökset, esimerkiksi työntekijöiden työolosuhteisiin liittyvät päätökset, tai taloudelliset ja ideologiset priorisoinnit niin organisaation sisällä kuten yleisemmin yhteiskunnassa.

Samanaikaisesti kun resurssit vähenevät ja työikäisen väestön keski-ikä nousee, tulisi työter- veyshuollon osoittaa tulosvastuuta, tehostaa työmenetelmiään ja kehittää osaamistaan. Tämä johtaa työterveysyksiköiden sisällä tarpeeseen analysoida toiminta-alaa ja tarpeeseen valita vaihtoehtoisia toimintamalleja. Oman erikoisalan tietoperustan lisäksi tarvitaan lisäksi uusia yhteistyömalleja ja uusia toimintateorioita.

$\mathrm{J}^{\mathrm{c}}$ otta olisi mahdollista vaikuttaa omaan toiminaan ja valita vaihtoehtoisia toimintamalleja sekä kehittää oppivaa ympäristöä, tulee tärkeäksi lisätä tietoisuutta muutoksesta ilmiönä, eri vaiheista muutosprosessin aikana, niin ympäristön eri tasojen välillä kuin suhteessa työterveyshuoltoon.

Muutos ja kehitys nähdään usein synonyymeinä, mutta muutos ei automaatisesti johda kehitykseen ts. johonkin parempaan. Tärkeiksi kysymyksiksi muodostuvat, miten muutos syntyy, miten staattinen tila vaihtuu dynaamisemmaksi, mitkä vaiheet sisältyvät muutokseen? Voiko muutosprosessiin vaikuttaa, voiko sen kulkua ja kattavuutta ohjata?

Tutkimuksessani käsitellään sosiaalisten systeemien sisäisiä ja ulkoisia edellytyksiä muutokselle. Systeemi koostuu työterveyshuoltoyksiköiden työntekijöistä ja heidän käsityksistään omasta työstään sekä toimintaan vaikuttavista erilaisista elementeistä.

\ouzesin \& Micon (1979) malli kuvaa muuXoksia julkisten palveluorganisaatioiden sisällä. Näiden organisaatioiden rakenteet luovat tilanteita, joissa ristiriitaisuudet, erot ja konfliktit ovat luonteenomaisia piirteitä. He jakavat organisaatiot kolmeen alueeseen poliittiseen, hallinnolliseen sekä professionaaliseen. Tutkimukseen sisältyy myös neljäs taso eli työterveyshuoltopalvelujen käyttäjät, ts. organisaatioiden työntekijät. Alueilla otaksutaan olevan eri näkemykset toiminnan tavoitteista, työmenetelmistä ja arvioinnista. Myös alueiden normit, työtavat ja muutosrytmit eroavat toisistaan. Poliittinen alue reagoi poliittisen sektorin tarpeisiin, hallinnollinen teknologisen ja taloudellisen sektorin tarpeisiin, professionaalinen kulttuurisen sektorin tarpeisiin, kun taas käyttäjät ovat herkkiä jokai- 
sen eri alueen tarpeisiin. Joka alue taistelee aktiivisesti ylläpitääkseen tasapainoa ja vastustaa sekä ympäristön muutoksia että muutoksia oman alueen sisällä. Samanaikaisesti toimintaan kohdistuu jatkuva muutoksen tarve johtuen alueiden erilaisista tarpeista ja keskenään ristiriitaisista toimenpiteistä.

Jatkuva muutospaine sekä työterveyshuoltoon kohdistuvat ristiriitaiset odotukset ja vaatimukset ovat verrattavissa Kouzesin ja Micon malliin. Tutkimus tuo esille ristiriitaisuuksia organisaatioiden eri tasojen välillä. Nähdään mm., miten työterveyshuollon asiantuntijoilla ja yritysten johdoilla usein on toisistaan poikkeavat käsitykset toiminnan tavoitteista, toiminnan tehokkuudesta ja laatunormeista.

$\mathrm{N}^{2}$ adler (1988) kuvaa erilaisia muutoksia monimutkaisissa organisaatioissa. Hän korostaa kahta ulottuvuutta muutoksessa, laajuutta ja aikaulottuvuutta. Toiminnan kannalta tulee tärkeäksi ajoissa ennakoida muutoksen tarvetta. Ennakoidun muutoksen aikana toimijoilla itsellään on mahdollisuus vaikuttaa muutokseen, sen laajuuteen ja kulkuun. Sitä vastoin reaktiivista, "uudelleenluomisen" muutosta on vaikeata hallita, se rikkoo organisaation aikaisemmat rakenteet ja strategiat. Suhteessa työterveyshuoltoon tämä voisi tarkoittaa, että muutokset pitäisi lähteä liikkeelle yhteisistä visioista ja toteutua ennen kuin ympäristön vaatimukset pakottavat niihin.

Tärkeäksi kysymykseksi muodostuu, minkälaisissa olosuhteissa muutos syntyy? Muuttuneet ulkoiset ehdot tai uudet ongelmat eivät aina johda muutosprosesseihin organisaatioissa. Ongelmat voidaan kieltää tai sulkea pois.

$\mathrm{K}$ urt Lewinin (1952) kenttäteoria on muuosprosessin tunnetuimpia teoreettisia malleja. Hänen mallinsa kuvaa suunniteltua muutosta sosiaalisessa systeemissä. Lähtökohtana on oletus, että suhteet systeemin sisällä muodostavat dynaamisen kokonaisuuden, jossa eri voimakentät tasapainottavat toisiaan. Muutos käynnistyy, kun joku voimakenttä systeemissä joko vähenee tai lisääntyy. Sosiaalisessa systeemissä on sekä voimakenttiä, jotka edesauttavat muutosta, että sellaisia jotka vastustavat. Muutos voidaan siten aikaansaada joko lisäämällä muutokseen pyrkiviä voimia tai vähentämällä muutosta vastustavia.

ikaisemman tilan sulattaminen on välttämä-
tön muutoksen käynnistämiseksi. Tämä tarkoittaa tekoja, jotka rikkovat eri voimien välistä tasapainoa niin, että systeemi järkkyy. Työryhmässä teot voivat kohdistua esim. aikaisempia työtapoja, tietopohjaa tai käsityksiä vastaan, jolloin tulee välttämättömäksi luopua tai muuttaa niitä. Tämä johtaa ryhmän jäsenillä epävarmuuden ja turvattomuuden tunteisiin. Tässä vaiheessa tulee tärkeäksi ylläpitää sosiaalista tukea ja vahvistaa ryhmän jäsenten turvallisuudentunnetta. Uuteensiirtymisen vaiheessa on mahdollista toteuttaa tekoja jotka muuttavat suhteita sosiaalisessa systeemissä. Tässä vaiheessa tulee tärkeäksi helpottaa ryhmän jäsenten mahdollisuuksia toteuttaa uusia tekoja. Tämä voisi tarkoittaa, että kaikilla työyhteisön jäsenillä olisi mahdollisuus osallistua muutokseen esimerkiksi arvioimalla tilannetta ja tuomalla esille tulevaisuuden toivomuksia. Muutoksen viimeisessä vaiheessa systeemi on saavuttanut uuden tilan ja siirtynyt tasapainoon.

A rgyris \& Schön (1978) kuvaavat laadullisia vaiheita organisaatioiden muutoksessa. $\mathrm{He}$ erottavat kolmea eri laatuista muutosta: muutokset, jotka syntyvät kun toimijat oppivat löytämään ja oikaisemaan virheitä (SINGLE-LOOP-LEARNING), muutokset, jotka syntyvät kun luodaan uusia toimintateorioita (DOUBLE-LOOP-LEARNING), sekä muutokset organisatorisella tasolla, joita luodaan reflektoimalla sitä, miten oppiminen aikaisemmin on tapahtunut (DEUTERO-LEARNING).

Ongelmana on että organisaatioissa yleensä priorisoidaan pysyvyyttä ja tasapainoa ja luodaan oppimisjärjestelmiä, jotka tukevat "single-looplearningia“. Tämä ei ainoastaan johda tehottomaan ongelmaratkaisuun, vaan myöskin defensiiviseen ryhmädynamiikkaan. Sekä Morgan (1986) että Argyris \& Schön puhuvat niistä sosiaalisista prosesseista, jotka johtavat ryhmäajatteluun. Ryhmäpaine saa yksittäiset jäsenet toimimaan ryhmän odotusten, normien ja arvojen 
mukaan. Ristiriitaisuudet organisaatioissa eivät sinänsä ole ongelma, vaan ongelmaksi muodostuu se, että ristiriitaisuuksia ei avoimesti pohdita. Sosiaalisissa organisaatioissa tulee erityisen tärkeäksi reflektoida ympäristön muutoksia ja haasteita. Tämä edellyttää oppimissysteemiä, joka tukee "DOUBLE-LOOP-LEARNINGIA", ja tarkoittaa keskeisten normien, oletusten ja toimintateorioiden avointa analysointia, kyseenalaistamista, testausta ja uudelleen rekonstruointia.

$\mathrm{E}$ dellä kuvattujen mallien mukaan muutos siältää siirtymistä aikaisemman tilan sulattamisesta uuteensiirtymisen vaiheeseen, ts. siirtymistä tilaan jolloin tulee mahdolliseksi suorittaa uusia tekoja. Tämä on verrattavissa siirtymisestä single-loop-learningista double-loop-learningiin, johon sisältyy kyky luoda uusia toimintateorioita. Tulee tärkeäksi lisätä ymmärrystä siitä, mitä uudet toimintatavat edellyttävät. Mitä aikaisemman tilan sulattaminen ja uuteen siirtyminen edellyttää, mitä tapahtuu molempien tilojen taitekohdassa?

Sekä kasvatus- että hoitotieteellisessä tutkimuksessa on paljon keskusteltu reflektoinnista ja reflektiivisesta toiminnasta (esim. Ahteenmäki-Pelkonen 1997, Järvinen 1990, Kolb 1984, Korkeakoski 1997, Leino 1995, Munnukka 1997, Sarvimäki 1988, Van Manen 1977). Toimintaalueilla on yhteisiä piirteitä. Esimerkiksi sekä opetukseen että terveysneuvontaan sisältyy kyky tukea muutosprosessia. Molemmilla alueilla syntyy kysymyksiä, jotka mm. liittyvät muutoksiin ympäristön odotuksissa toiminnan suhteen, uuden tiedon tarpeeseen tai muutoksiin omassa ammattiroolissa tai suhteessa oppilaaseen tai asiakkaaseen (potilaaseen).

$\mathrm{G}$ rimmet et al. (1990) yhdistävät käsityksiään reflektoinnista kolmeen perspektiiviin. Lähtökohtana perspektiiveille on Habermasin käsitys erilaisista suhtautumistavoista tietoon. Tekninen suhtautuminen perustuu "reflection as instrumental mediation of action" käsitteeseen jossa tietoa käytetään ohjaamaan tai kontrolloimaan toimintaa. Hermeneuttinen suhtautuminen perustuu "reflection as deliberating among competing views of teaching“"-käsitteeseen, jossa tieto voi toimia informaationa ja osoittaa vaihtoehtoisia käytännön valintoja. Kolmas suhtautuminen ts. emansipatorinen perustuu käsitteeseen "reflection as reconstructing experience" ja tietoa käytetään toiminnan ymmärryksen ja muutoksen aikaansaamiseksi.

Suhteessa tähän tutkimukseen kolmas perspektiivi tulee mielenkiintoiseksi. Suhtautuminen johtaa Grimmetin et al.in mukaan sekä toimintatilan uuteen ymmärrykseen, oman ammattiroolin uuteen ymmärrykseen että toiminnan "itsestään selvyyksien" uuteen ymmärtämiseen.

$\mathrm{T}_{\mathrm{t}}$ oimintatavan uusi ymmärrys voisi suhteessa työterveyshuoltoon tarkoittaa, että eri ammattiryhmien edustajat analysoivat yhdessä esimerkiksi terveysneuvonnassa esiintyneitä ongelmia, esimerkiksi: Minkä takia neuvonta tässä tapauksessa ei tuottanut toivottua tulosta? Mitkä tekijät ovat tärkeitä neuvontatilanteessa?

Oman ammattiroolin uusi ymmärrys voisi tarkoittaa esimerkiksi sitä, että analysoi omaa suhtautumistaan työtehtäviinsä ja miten oma suhtautuminen vaikuttaa hoitosuhteeseen ja asiakkaan kanssa tapahtuvaan vuorovaikutukseen.

Toimintateorioiden muuttaminen edellyttää yksittäisten työntekijöiden, työryhmän ja johdon taholta sekä tahtoa, uskallusta että kykyä analysointiin ja reflektointiin. Tämä tarkoittaa kriittistä suhtautumista toiminnan "itsestään selvyyksiin“ ja sisältää esimerkiksi käsitteiden määrittelyä, mitä "laadukas toiminta" sisältää, mitä "kokonaisvaltainen suhtautuminen asiakkaan ongelmiin" tarkoittaa? Tämän lisäksi kyseenalaistetaan ja analysoidaan yhdessä organisaatiossa vallitsevia normeja, päätösprosesseja ja toimintamalleja. Analysoidaan avoimesti niitä sosiaalisia prosesseja, jotka johtavat ryhmäajatteluun ja edistetään kaikkien työryhmän jäsenten mahdollisuuksia vaikuttaa omaa työtä koskeviin päätöksiin.

Jotta muutos syntyisi, edellytyksenä on toisin sanoen "reflection as reconstructing experience“. Kokemus ei synny passiivisesti. Kokemus rakentuu henkilökohtaisesti ja syntyy ihmisen ja hänen ympäristönsä aktiivisen vuorovaikutuk- 
REFLEKTIO KOKEMUKSEN UUDELLEENKONSTRUOINNIN MERKITYKSESSÄ(Grimmet et al):

- uusi ymmärrys toimintatilanteeseen

- uusi ymmärrys omasta ammattiroolista

- uusi ymmärrys valmiina annettuihin olettamuksiin ("ta för givna antaganden")

\section{MUUTTUNEET TOIMINTATEORIAT}

Kuvio 2. kuvaa miten "reflection as reconstructing experience" mahdollistaa muutoksen.

sen tuloksena. Tiedon lähteenä toimii ts. toiminnan sosiaalinen konteksti ja perustuu kykyyn käyttää hyväksi sekä henkilökohtaista että jaettua kokemusta.

\section{Lähteet}

AHTEENMÄKI-PELKONEN, L. (1997) Kriittinen näkemys itseohjautuvuudesta. Systemaattinen analyysi Jack Mezirowin itseohjautuvuuskäsityksistä. Helsingin yliopiston Kasvatustieteen laitos. Tutkimuksia 157

ARGYRIS, C. \& Schön, D. (1978) Organizational learning: A theory of action perspective. Massachusettes: Addison-Wesley, Reading.

GRIMMET, P., Erickson, G.L., Mackinnon, A. M., Ricken, T.J. (1990) Reflective practice in teacher education. I: Encouragin reflective practice in education. New York: Teachers college press 20-38

HABERMAS, J. (1971) Knowledge and human interests. Boston: Bacon Press

JÄRVINEN, A. (1990) Reflektiivisen ajattelun kehittyminen oppettajankoulutuksen aikana. Jyväskylän yliopisto. Jyväskylä: Kirjapaino oy Sisä-Suo$\mathrm{mi}$

KALIMO, R. \& Toppinen, S. (1997) Työuирumus Suomen työikäisellä väestöllä. Helsinki: Työterveyslaitos.

KOLB, D.A. (1984) Experiental learning. Experience as the source of learning and development. Engelwood Cliffs, N J: Prentice Hall.

KORKEAKOSKI, E. (1997) Opettajan tavoitetietoisuusopetuksessa ja oppimisessa. Acta Universitatis Tamperesis. ser. A. vol. 533. Vammala: Vammalan kirjapaino oy.

KOUZES, J. \& Mico, P. (1979) Domain Theory An introduction to organizational behavior in human service organizations. The journal of behaviral science, $15,445-469$

LEHTO, A-M. \& Sutela, H. (1998) Tehokas, tehokkaampi, uирunut. Tutkimuksen tuloksia 1977-1997. Vantaa: Tilastokeskus.

LEINO, J. (1995) Cooperative reflection in teacher education: A Finnish perspective. Teacher education quarterly, 22 (1) 31-38.

LEWIN, K. (1952) Field theory in social science. London: Tavistock.

LUOPAJÄRVI, T. (1997) Fysikaalisista hoidoista työkyvyn ylläpitoon. I Työfysioterapia. Yhteistyö työja toimintakyvyn hyväksi. Helsinki: Työterveyslaitos.

MORGAN, G. (1986) Images of organization. Beverly Hills: Sage Publications.

MUNNUKKA, T. (1997) Hoitamaan oppiminen ja opettaminen. Acta Universitatis Tamperensis 579 Vammala: Vammalan kirjapaino oy.

NABLER, D. (1988) Organizational frame bending: types of change in the complex organization. I Corporate transformation. San Francisco: Jossey Bass. 66-83.

RANTANEN, J. (1997) Työterveyshuollon kehitys. I: Hyvä työterveyshuoltokäytäntö. Opas toiminnan suunnitteluun ja seurantaan. Helsinki: Sociaali-ja Terveysministeriö \& Työterveyslaitos. 10-14

SARVIMÄKI, A. (1988) Knowledge in interactive pracitce disciplines. An analysis of knowledge in education and health care. University of Helsinki, Department of Education, Research Bulletin 68 Helsinki.

SCHUTZ, D. (1967) The phenomenology of the social word. Evanston, IL: Northwestern University press.

Van MANEN, M. (1977) Linking ways of knowing with ways of beeing practical. Curriculum inquiry. $6,3,205-228$

Lectio praecursoria Helsingin yliopiston kasvatustieteen laitoksen väitöstilaisuudessa 25.9.1999. Vastaväittelijänä toimi dosentti Siv Their. 